\title{
DETERMINANTS OF LEARNING ORIENTATION AND MOTIVATION ON EMPLOYEES PERFORMANCE
}

\author{
Sri Ismulyaty dan Etty Puji Lestari \\ The Open University Faculty of Economics \\ srismu@ut.ac.id dan ettypl@ut.ac.id
}

\begin{abstract}
ABSTRAK
Sri Ismulyaty dan Etty Puji Lestari; Tujuan perusahaan adalah untuk mengembangkan berbagai strategi pemasaran untuk meningkatkan profitabilitas perusahaan, sehingga manajemen perusahaan untuk fokus pada upaya untuk mengidentifikasi pelanggan, karena filosofi pemasaran menunjukkan bahwa keuntungan yang dapat diciptakan melalui kepuasan yang dirasakan oleh pelanggan . motivasi kerja diyakini berpengaruh dalam membangkitkan, mengarahkan, dan mempertahankan perilaku dalam lingkungan kerja untuk mengembangkan prestasi. Beberapa studi telah menyatakan adanya hubungan antara motivasi kerja dengan kinerja karyawan. Tujuan dari penelitian ini adalah untuk menganalisis pengaruh belajar orientationof 46 kinerja karyawan di Universitas Terbuka. Kami menggunakan metode stratified random sampling. Data yang digunakan dalam penelitian ini adalah data primer dari responden dan data sekunder. Hasil penelitian menunjukkan bahwa ada hubungan positif antara orientasi pembelajaran dengan kinerja karyawan ditunjukkan oleh nilai estimasi sampel asli dari 0,854 dan t-statistik dari 4228 yang lebih besar dari t-test 1,96. Sedangkan motivasi kerja hubungan dan kinerja memiliki dampak negatif.
\end{abstract}

Sri Ismulyaty dan Etty Puji Lestari; The company's goal is to develop a variety of marketing strategies to improve the profitability of the company, so the company's management to focus on efforts to identify the customer, because the philosophy of marketing shows that the profit can be created through the satisfaction perceived by customers. Work motivation is believed to be influential in arousing, directing, and maintaining behavior in the work environment to develop achievement. Several studies have suggested a link between work motivation with employee performance. The purpose of this study was to analyze the influence of learning orientationof 46 employee performance at the Open University. We used stratified random sampling method. Data used in this study were primary data from the respondents and secondary data. The results showed that there is a positive relationship between learning orientation with employee performance shown by the value of the original sample estimate of 0.854 and a t-statistic of 4,228 is greater than the t-test is 1.96 . While the relationship work motivation and performance have negative impact.

Keywords : learning orientation, motivation, performance

\section{INTRODUCTION}

The marketing concept formally need for marketers to make his company into a customer-centered (Augusty, 2000). The market is very dynamic. Customer demand reflecting varied market often increase over time along with changes in the surrounding environment. Slater and Narver (1995) describe the outcomes of the implementation of corporate strategy as consumer satisfaction, the success of new products, increased sales and profitability, because it is measure of marketing performance achievements obtained from the overall marketing activity of an organization.

Learning is defined as a response newer or better activities, when faced with the reality learning environment changes, changes that ultimately will determine the innovation environment (Daft and Schon, 1978). A new determination of the competence of the company is designed and evaluated with a capability of confidence and consistency and still exist in achieving the goals/objectives (Augusty, 2000) and suggests that the learning organization is targeted towards better results. If the firm uses strategies that appropriate as a target, then the company needs a consistent way is to develop resources that match the capabilities of the company. Likewise dominoes study (2007) said that the relationship between learning orientation with performance.

Variable work motivation and its influence on the success of marketing contained in the conception process in which the salesperson supervision in the absence of a clear marketing plan of the leadership or marketing manager, will bring salespeople work attitudes are less positive as the tendency to work more relaxed failed high-risk, low motivation level will have an impact on the achievement of marketing objectives (Menon, et al, 1996). These findings support the notion that there is a relationship between work effort, and job performance and that motivation would influential in arousing, directing and maintaining 
behavior in the work environment to produce achievement. Thus if the target or standard work, the system rewards both financial and career incentives in the form of clearly defined management. This will bring up the motivation that drives salesperson diligently perform an activity for achievement, accomplishment which can be either an increase in performance sales of such high sales volume achievement .

Open University (UT) is a state university $45^{\text {th }}$ in Indonesia, which was inaugurated on September 4, 1984, pursuant to Presidential Decree No.41 of 1984 (www.ut.ac.id ). UT was established with the aim to provide ample opportunity for citizens to obtain higher education. UT also develop academic and professional education programs in accordance with the real needs of the construction that has not been developed by other universities. To improve the quality of higher education, the performance of its human resources (employees) must also be increased. Many things affect the performance of the employees at the Open University, but that is the focus of this study is the factor of learning and motivation.

Studies by Asatuan (2004) shows the relationship between work motivation with performance. This article is the existence of studies Asatuan (2004) and dominoes (2007), so the combination of the two studies combined will give a new research models for the development of science, so that the role of the Open University academic institutions for the better.

\section{METHODOLOGY}

The operational definition of a variable is the withdrawal limit further elucidate the specific characteristics of a more substantive than a concept. The goal is that researchers can achieve an appropriate measurement tool with the nature of the variables that are already defined the concept, then the researcher must enter the process or the operation of measuring instruments which will be used for the quantification of symptoms or variables examined. The operational definition of the variables can be seen in Table 1 below.

Table 1. Indicators of Research Variables

\begin{tabular}{|c|c|c|}
\hline Variable & Dimensions & Attributes \\
\hline $\begin{array}{l}\text { Learning } \\
\text { Orientation }\end{array}$ & 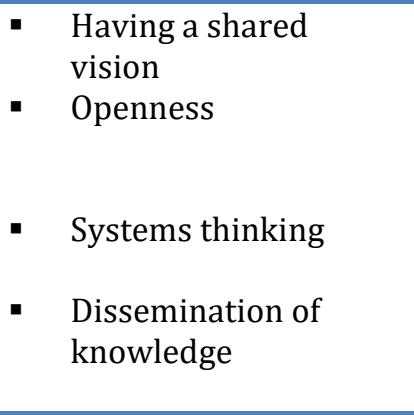 & $\begin{array}{l}\text { - Trying to do the job with the consent } \\
\text { of each parts } \\
\text { - Trying to conduct activities in a } \\
\text { manner not afraid of criticism in the } \\
\text { way of doing business } \\
\text { - Each do the job thinking that is easy to } \\
\text { solve } \\
\text { - Each new job either in the model / } \\
\text { design or other design always tries to } \\
\text { spread to other employees }\end{array}$ \\
\hline $\begin{array}{l}\text { working } \\
\text { motivation }\end{array}$ & $\begin{array}{l}\text { - } \quad \text { Orientation learning } \\
\text { - } \quad \text { Ability to work hard } \\
\text { ability to work smart } \\
\text { and careful }\end{array}$ & $\begin{array}{l}\text { - } \quad \text { Strive to always learn the new design } \\
\text { Enhanced learning any new emerging } \\
\text { work } \\
\text { - Ability to work hard to increase } \\
\text { activity } \\
\text { - Ability to work more closely and } \\
\text { intelligent }\end{array}$ \\
\hline performance & 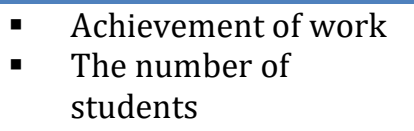 & $\begin{array}{l}\text { - Job attainment percentage } \\
\text { - } \quad \text { The number of students }\end{array}$ \\
\hline
\end{tabular}

The data collected from the questionnaires of preparation, tabulation, and data on the application of research approaches. Further tabulation of the results of a questionnaire to give a score according to the system which has been established that using an interval scale 10. This research model is a model of causality (relationship / influence causal) so as to test the analytical tools used in this study is a model of SEM (Structural Equation Modeling) which is operated through the Smart PLS (Partial Least Square).

The purpose of the Partial Least Square (PLS) is helping researchers to obtain latent variables for prediction purposes. According to Chin, 1998 (the Imam Ghozali, 2006) states that because PLS does not assume the existence of a particular distribution for parameter estimation, the parametric techniques to 
test the significance of the parameters is not required. PLS evaluation model based on predictions that have pengukutan non-parametric nature. In the PLS model of evaluation are the following stages :

\section{Outer Model}

In the measurement model or outer PLS models with reflexive indicators evaluated convergent validity and discriminat validity of the indicators and composite reliability indicator for the block. While the formative indicators are evaluated based on its substantive content that compares the magnitude of the relative weight and look siginifikansi of the weight size (Chin, 1998 in Imam Ghozali, 2006). Latent variables are variables that can not be measured directly (should the indicators or questionnaire). While the reflexive indicator is a variable that is affected by latent variables. So the model is a reflexive indicator construct or latent variable diijelaskan by indicator or direction of the relationship of the construct to the indicators. The indicators measure the same thing about the construct, so an indicator should have a high correlation. If one indicator disposed of, then the construct will be affected. In a model is seen as a formative indicator variables affecting the latent variables. So the model formative indicators are indicators affect construct or relationship of indicators to construct, inter- correlated indicators are assumed to not be discarded so that the indicator will not affect the construct .

Convergent validity of the measurement model with reflective indicators assessed by the correlation between the item scores or component scores with construct scores were calculated by PLS. The size of individual reflexive said to be high if more than 0.70 correlated with the construct to measure. However, for the initial study of the development of measurement scales loading value of 0.50 to 0.60 are considered sufficient (Chin, 1998 in Imam Ghozali, 2006). Discriminat validity of the measurement model with reflective indicators assessed by the measurement of the construct of cross loading. If the correlation with the items measuring the construct is greater than the size of the other constructs, then it shows that the latent constructs predict the size of the block they are better than the block size on the other.

Another way is to look at the value of the square root of average variance extracted (AVE) of each construct with the correlations between constructs with other constructs in the model. If the root of the AVE value of each construct was greater than the value of the correlation between the construct with other constructs in the model, then it is said to have good grades discriminant validity (Fornell and Larcker, 1981 in Imam Ghozali, 2006). In addition compositre also evaluated the reliability of the block indicator. Composite reliabilty blocks construct an indicator that measures can be evaluated by two kinds of sizes of internal and Cronbach 's Alpha consistensy.

\section{Inner Structural Model or Model}

Inner structural model or models are evaluated by looking at the percentage of variance explained by looking at the value of R square for the dependent latent constructs, Stone-Geisse Q-square test for predictive relevance and significance of the $t$ test and the structural path coefficient parameter. Same interpretation as the interpretation of the regression analysis .

\section{Hypothesis Testing}

For the entire hypothesis testing method is used Partial Least Square (PLS). PLS is a powerful method of analysis because many of the assumptions are not based (Ghozali, 2006). With the PLS method can be tested using the model assumptions : the data should not normally distributed, a scale of measurement can be nominal, ordinal, interval and ratio, the number of samples should not be large, the indicator should not be in the reflexive form (can be reflexive and formative indicators) and model should not be based on the theory (Ghozali, 2006).

With the $t$ test, which is to test the significance of the constants and the independent variables included in the equation if the individual effect on the value of the dependent variable (Ghozali, 2001). For this testing is done by looking at the output with the help of an application program PLS Graph. If the count value $\mathrm{T}<\mathrm{T}$ table, then the null hypothesis is rejected, (significant regression coefficients) and the alternative hypothesis stated in this study received at a significance level of 5\% (five percent). Measurement of the percentage effect of all independent variables on the dependent variable values, indicated by the R-square coefficient of determination (R2) between 1 and zero, where the value of $R$ square (R2) close to unity gives the percentage of large effect (Chin, 1998). Structural equation model in this study will be completed by SmartPLS program.

- Hypothesis 1 : Learning orientation is formed from the dimensions of a shared vision, openness, systems thinking, dissemination of knowledge, and self-control. The better orientation of learning, the better of performance. 
- Hpothesis 2 : Motivation is formed from the dimensions of the ability to work hard, ability to work smart and careful. The better motivation to work, the better the performance.

\section{RESULT AND DISCUSSION}

We distributed 146 questionnaires. From the total questionnaires distributed, the completed and returned questionnaire is 46 questionnaire. Questionnaire caused respondents who did not return in the middle of the bustle so did not have time to answer questionnaire. Therefore, the amount of data that can be processed for analysis is a number of 46 questionnaires. Calculation of the number of questionnaires distributed to the collected contained in Table 2 below:

Table 2. Percentage of Questionnaire Delivery and Returns

\begin{tabular}{|clcc|}
\hline No. & \multicolumn{1}{c}{ Description } & Amount & Percentage \\
\hline 1. & Questionnaires were distributed & 146 & $100 \%$ \\
\hline 2. & Questionnaires were returned & 80 & $54.8 \%$ \\
\hline 3. & Questionnaires were not returned & 66 & $45.2 \%$ \\
\hline 4. & Incomplete questionnaires & 20 & $13.69 \%$ \\
\hline 5. & Questionnaires which can be processed & 46 & $31.5 \%$ \\
\hline
\end{tabular}

Testing the validity of the data use PLS Model Outer Convergent software. Validity is seen that the value of the square root of average variance extracted (AVE) of each construct in which the value must be greater than 0.5. AVE table describes the value of AVE and root AVE of the construct instructional orientation, work motivation and performance. It can be seen that each of these constructs have AVE values above 0.5. This suggests that each of these constructs has good validity value of each indicator or the questionnaire used to determine the orientation relationship of learning, motivation and performance work as valid. Table 3. AVE can be seen in the following:

Table 3. Average Variance Extracted Index (AVE)

\begin{tabular}{|lc|}
\hline Learning Orientation & $\begin{array}{c}\text { Average variance } \\
\text { extracted (AVE) }\end{array}$ \\
\hline Motivation & 0.839 \\
\hline Performance & 0.944 \\
\hline
\end{tabular}

\section{Test of Reliability}

A composite of data said to be reliable if the reliability of more than 0.7 . From the table it can be seen the composite reliability of each construct or latent variable that has a composite reliability values above 0.7 which indicates that the internal consistency of between variables have good reliability.

Tabel 4. Composite Reliability

\begin{tabular}{|lc|}
\hline Orientasi Pembelajaran & Composite Reliability \\
\hline Motivasi & 0.963 \\
\hline Kinerja & 0.971 \\
\hline
\end{tabular}

\section{Full Structural Model}

In Figure 1, it can be seen that each construct of each variable is explained by each indicator. Outer loading that value is negative and less than 0.5 in remove from the model in this case dikeluarkna $\mathrm{mk}_{3}$ indicator of the model. 


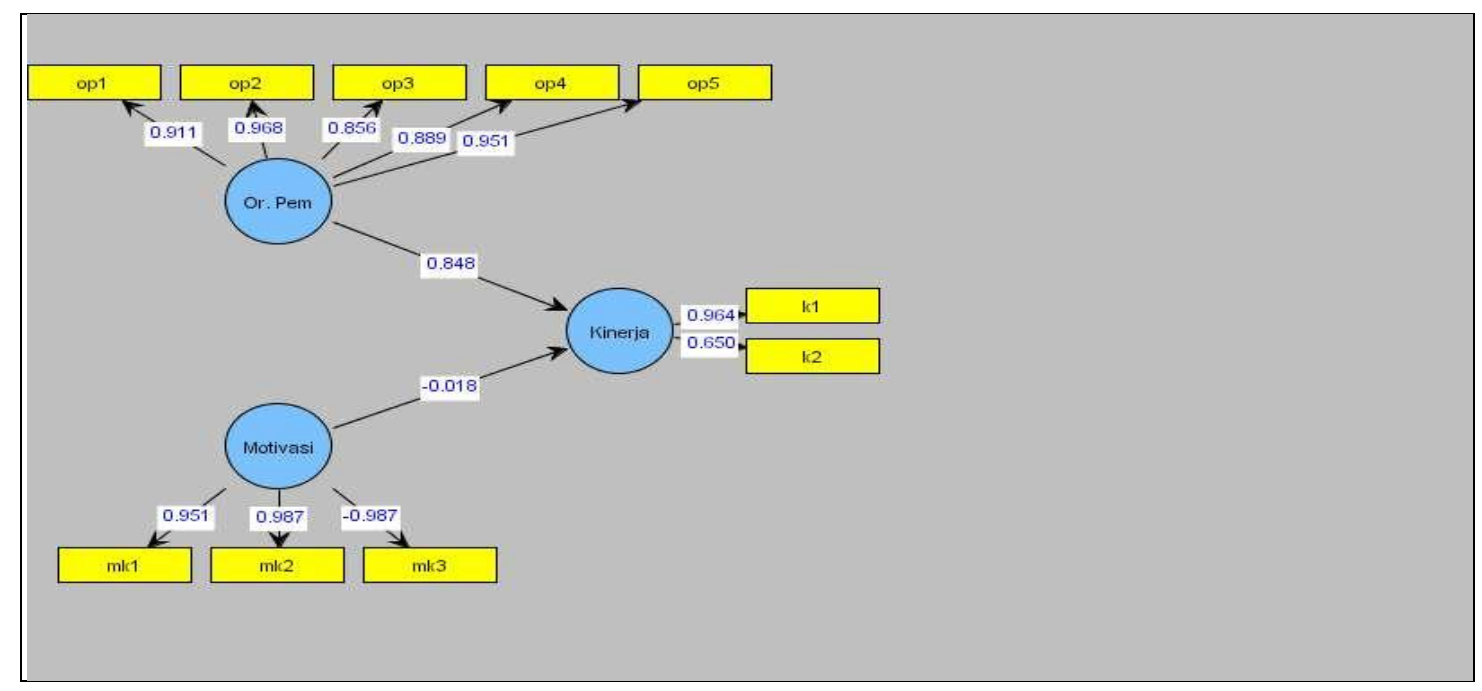

Figure 1. Full initial model

Next step, run back with the remaining indicator. Thus resulting outn put on the table as full initial model, so that each variable met the criteria convergent validity.

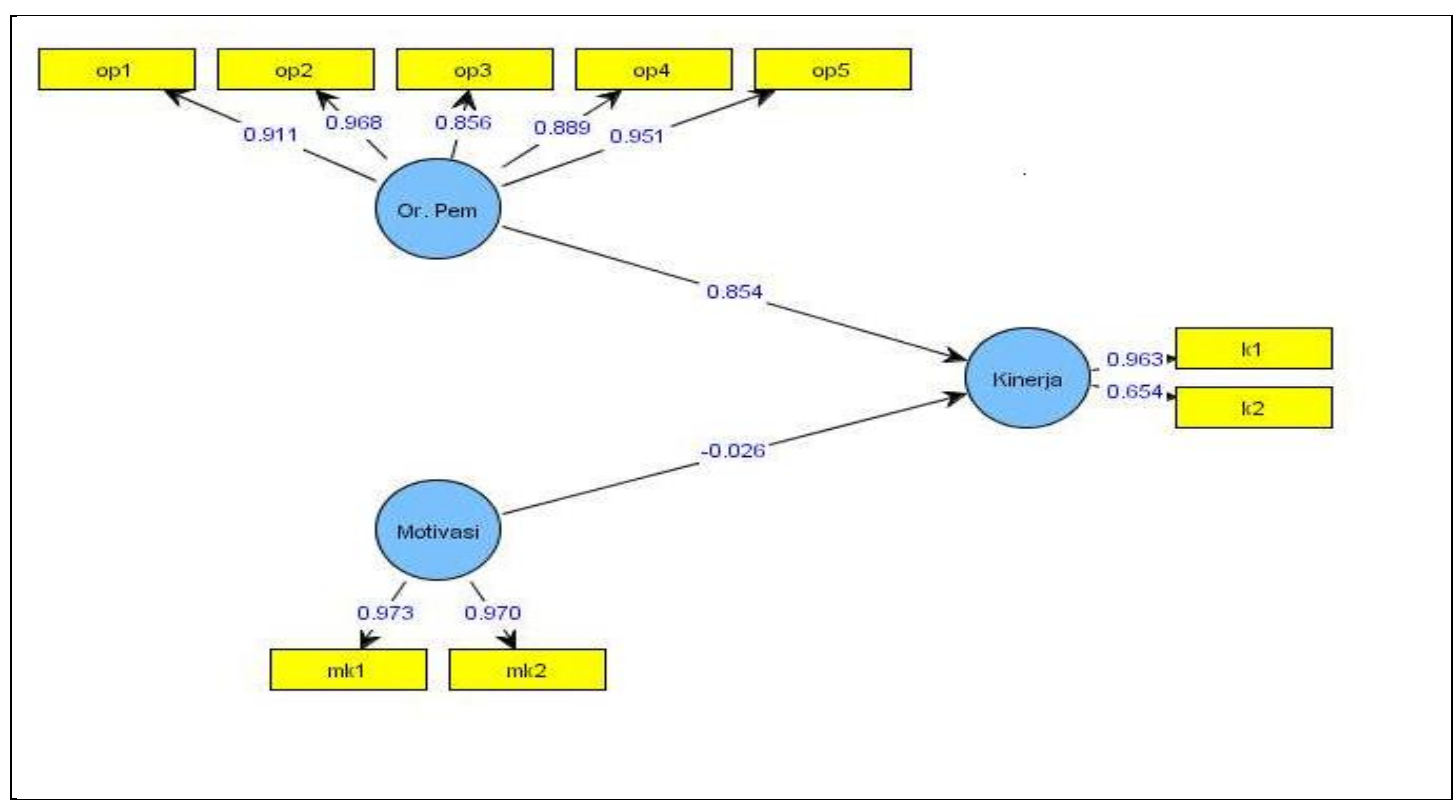

Figure 2. Model After Elimination Indicator $\mathrm{mk}_{3}$

Table 5. Outer loading After Revision, with the Removal of $\mathrm{mk}_{3}$

\begin{tabular}{|lcccc|}
\multicolumn{2}{c}{$\begin{array}{c}\text { original sample } \\
\text { estimate }\end{array}$} & $\begin{array}{c}\text { mean of } \\
\text { subsamples }\end{array}$ & $\begin{array}{c}\text { Standard } \\
\text { deviation }\end{array}$ & $\begin{array}{c}\text { T- } \\
\text { Statistic }\end{array}$ \\
\hline Learning orientation & & & & \\
\hline op $_{1}$ & 0.911 & 0.901 & 0.034 & 27.16 \\
\hline op $_{2}$ & 0.968 & 0.969 & 0.006 & 155.42 \\
\hline op $_{3}$ & 0.856 & 0.853 & 0.044 & 19.345 \\
\hline op $_{4}$ & 0.889 & 0.89 & 0.045 & 19.652 \\
\hline op $_{5}$ & 0.951 & 0.951 & 0.016 & 57.959 \\
\hline Motivation & & & & \\
\hline
\end{tabular}




\begin{tabular}{|lcccc|}
\hline $\mathbf{m k} \mathbf{1}$ & 0.973 & 0.971 & 0.007 & 144.58 \\
\hline $\mathbf{m k} \mathbf{2}$ & 0.97 & 0.966 & 0.011 & 90.869 \\
\hline Performance & & & & \\
\hline $\mathbf{k}_{\mathbf{1}}$ & 0.963 & 0.968 & 0.019 & 50.516 \\
\hline $\mathbf{k}_{\mathbf{2}}$ & 0.654 & 0.588 & 0.203 & 3.219 \\
\hline
\end{tabular}

\section{Hypothesis Testing}

To test the hypothesis, it can be seen the value of t-statistic. Limits to reject and accept the proposed hypothesis is \pm 1.96 , where if the value of $t$ in the range-1.96 to 1.96 then the value of the hypothesis will be rejected or otherwise accept the null hypothesis $\left(\mathrm{H}_{0}\right)$. The results of the $\mathrm{t}$ - statistic estimation can be seen in the table result for the inner weight.

Hypothesis 1 stated that there is a positive relationship between learning orientation and performance indicated by the value of the original sample estimate of 0.854 and a t-statistic of 4,228 is greater than the t-test is 1.96 , thus hypothesis 1 is accepted. These results indicate that the learning activities that have been implemented in the UT for employees to have a strong influence to improve the skills of employees. Learning to academics such as training using OER (open eductaional resources), turnitin applications for academic and administrative training programs for administrative staff. The benefits of training among others accelerate everyday tasks and update knowledge.

Tabel 6. Result for Inner weight

\begin{tabular}{|lcccc|} 
& $\begin{array}{c}\text { original sample } \\
\text { estimate }\end{array}$ & $\begin{array}{c}\text { mean of } \\
\text { subsamples }\end{array}$ & $\begin{array}{c}\text { Standard } \\
\text { deviation }\end{array}$ & T-Statistic \\
\hline $\begin{array}{l}\text { Learning } \\
\text { orientation }-> \\
\text { performance }\end{array}$ & 0.854 & 0.883 & 0.202 & 4.228 \\
\hline $\begin{array}{l}\text { Motivation -> } \\
\text { performance }\end{array}$ & -0.026 & -0.05 & 0.223 & 0.117 \\
\hline
\end{tabular}

Hypothesis 2 states that the working relationship between motivation and performance is positive and significant, indicated by the value of the original sample estimate of 0.026 and a t-statistic of 0.117 which is smaller than the t-test is 1.96 thus hypothesis 2 was rejected. Thus the motivation was not the only one that affects the employee 's performance at the Open University. From closed questions was known that the dominant factor affecting performance is the provision of remuneration. As an institution that has been metamorphosed into a public service agency then UT is entitled to remuneration to its employees.

\section{CONCLUSION}

From the results of the study can be seen that learning orientation has a positive influence on employee performance at the Open University. While the motivation is not the dominant thing that determines the Open University employee performance improvement. Thus, as an institution that has hosted the Open University BLU should increase the motivation of employees, one of them by giving incentives. Through incentives karyawanya expected performance will increase.

\section{REFERENCES}

Aaker DA (1989), Managing Assets and Skill, The Kilt to asustainable competitive Advantage. California Management Review.

Asatuan, Agustina (2004), Studies on Orientation Management, Journal of Marketing Science Indonesia, Vol III, No. 1, BP UNDIP Semarang

Augusty FT, (2000), Marketing Management: A Strategic Approach, Diponegoro Universits Management Program

Barney, JB (1991), Firm Resource and Sustained Competitive Advantege, Journal of Management.

Calantone, R.J, Cavusgil, S.T, and Zhao, Y, (2002), Learning Orientation, Firm Innovation Capability, and Firm Performance, Industrial Marketing Management

Cohen and Levintal, (1998), New Product Development: The Performance and Time to Market trade off , 


\section{Management Science}

Dickson, P.R, (1996), The Static and Dynamic Mechanis of Competition: A Comment on

Hunt and Morgan"s Comparative Advantage Theory

Dodgson, M, (1993), Organizational Learning: A Review or Same Literaturs, Organization Studies

Hair, JR, Joseph F, Rolp E. Anderson, Ronald L. Tatham amd William C. Black, (1995), multivariate Date Analysis Readings, (Fourth Ed), Prentice Hall International, Inc

Hayek, Fredrick A (1935), Collectivist Economic Planning: Criticical Studies on The Possibilities of Socialisme, London; Routledge

Hofer, Charles W, \& Schendel, (1978), Strategy Formulation: Anallytical Concept West Publishing Linkages in Personal Selling, Journal of Marketing

Kiuk. Johanis M., (2007), Building a Marketing Performance towards Sustainable Competitive Advantage, Dissertation, Doctoral Program in Economics, Diponegoro University

Mahoney, Yoseph T, (1993), The Management of Resources and Resource of Management, Journal of Business Research 33, 91-101

Menon, Anil, Sundar G. Bharadwaj, P Phani Tej Adidam and Steven W. Edison (1999), Antecedents and Consequences : of Marketing Strategy Making A Model and a test", Journal of Marketing, 18 April, $18-40$.

Mc Gill, Michael E \& Slocum, John, (1992), Management Practise in Learning Organization, Organization Dynamic

Narver and Slater, (1990), "The Effect of a Market Orientation on Business Profitability", Journal of Marketing

Keats, B.W., and Hitt, M.A., (1988), A Casual Model of Linkages Among Environmental Dimensions Macro Organization Characteristics, and Performance, Academy of Management Journal, Vol.31, No.3. 570-598.

Pelham. W, (1997), Mediting Influence on The Relation Between Marketing Orientation and Profitability firm, Journal of Marketing Theori and Practise

Sujan, Harish, Barton A.Weitz \& Nirmalya Kumar, (1994), Learning Orientation, Working Smart, and Effective Selling, Journal of Marketing. 